\title{
Evaluation of Hydrocarbon Reserve in AD Field, Offshore Niger Delta
}

\author{
M. E. Nton'1, M. O. Adeyemi ${ }^{2}$ \\ ${ }^{1}$ Department of Geology, University of Ibadan, Ibadan, Nigeria \\ ${ }^{2}$ Department of Geology and Mineral Sciences, Crawford University, Igbesa, Nigeria \\ Email: ntonme@gmail.com,moyo_adeyemi@yahoo.com
}

How to cite this paper: Nton, M.E. and Adeyemi, M.O. (2021) Evaluation of Hydrocarbon Reserve in AD Field, Offshore Niger Delta. Open Journal of Geology, 11, 155-174.

https://doi.org/10.4236/ojg.2021.115009

Received: December 11, 2020

Accepted: May 17, 2021

Published: May 20, 2021

Copyright () 2021 by author(s) and Scientific Research Publishing Inc. This work is licensed under the Creative Commons Attribution International License (CC BY 4.0).

http://creativecommons.org/licenses/by/4.0/

\section{(c) (i) Open Access}

\begin{abstract}
This study was carried out to quantify uncertainty in the reserve estimate of hydrocarbon in the reservoirs of AD Field, offshore, Niger Delta. Three Dimensional (3D) seismic data and log suites of seven wells (AD1 to AD7), gamma ray, resistivity, neutron and bulk density logs, well deviation and checkshot data in AD Field acquired from companies in the area. Twelve faults (Fault1 to Fault12) were identified from seismic structural interpretation while Six hydrocarbon-bearing sand intervals (Sand A - F) were delineated from the petrophysical analysis. The sand intervals thin-out basin wards, suggesting a prograding sequence. The porosity of the sand intervals ranges between 0.19 and 0.32 , implying good to excellent porosity. The water saturation values ranged from 0.19 to 0.39 , indicates a prospective accumulation of hydrocarbon. Sand A reservoir had the largest accumulation of hydrocarbon in-place with hydrocarbon pore volume of 2343106 Reserve Barrel (RB), Stock Tank Oil-Initially-In-Place (STOIIP) of $175 \mathrm{MMbbl}$ and gas initially-in-place of $0.30 \mathrm{TCF}$. The coefficient of variation in the reserve estimates of the reservoirs ranged from 0.09 to 0.15 indicating very low uncertainty of substantial hydrocarbon reserve that could be exploited.
\end{abstract}

\section{Keywords}

Petrophysical Information, Uncertainty Analysis, Reserve Evaluation, Roll-Over Anticlines

\section{Introduction}

The Niger Delta basin is located in the Gulf of Guinea and represents one of the major Delta systems in the world (Figure 1). This basin sediment covers an area of approximately $75,000 \mathrm{~km}^{2}$ and progrades southwest from Eocene to the 


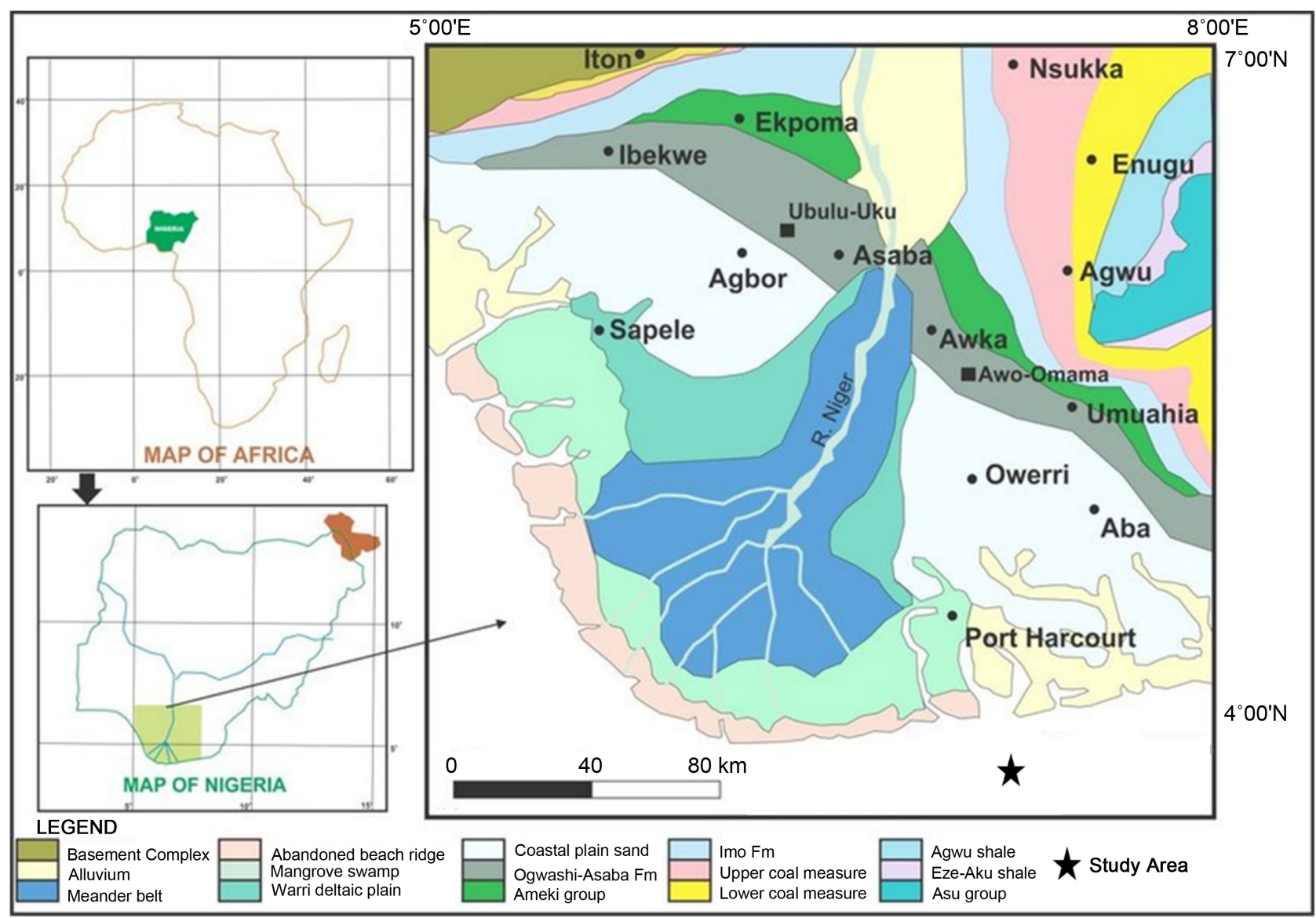

Figure 1. Map of the Niger Delta basin (After Nwanjide [1]).

present, forming different depobelts [1]. The basin rank (12th) among the best prolific petroleum belts worldwide and 1st in Africa [2]. The Niger Delta accounts for $2 \%$ to $5 \%$ of the present day sedimentary basins on earth with hydrocarbon reserves above 34.5 billion barrels (STB) of oil and 93.8 trillion cubic feet (TCF) of recoverable gas [3]. Continuous discoveries of hydrocarbon resources in the Niger Delta oil province have encouraged exploration and production activities [4]. The evaluation of hydrocarbon resource involves the integration of petrophysical interpretations from well log data with the structural interpretations from seismic data. This combination study would help to quantify subsurface hydrocarbon resource, identify the hydrocarbon prospects, leads, resource ranking, quantify uncertainty as well as provide information for well development [5]. The integration of seismic and well log information play key roles in hydrocarbon reserve evaluation [5] [6]. The commercial life of hydrocarbon reservoirs often begins with exploration goes through development and ends with the exploitation of hydrocarbon. Reservoir characterization has evolved as a result of the integration of geology, geophysics, petrophysics, and geostatistics as a tool for providing better understanding of subsurface reservoirs and their homogeneities [7]. Several authors have contributed to advancement in techniques used in quantifying the influence of uncertainties in reservoir modelling. Garb 
[8] proposed the use of both deterministic and probabilistic techniques for hydrocarbon evaluation while Caldwell and Heather [9] considered analogy, volumetrics and performance analysis as the three main categories for reservoir evaluation. Geological concepts and reservoir characteristics used in the evaluation of hydrocarbon reserves are often full of uncertainty regarding geological structures, hydrocarbon seals, and hydrocarbon charge. The inability to measure hydrocarbon resource adequately could result into field development failure [10]. The use of practical methods for estimating the uncertainty associated with the geology of reservoirs without compromising accuracy is of utmost importance in reservoir evaluation and field development programs [11]. Three dimensional seismic interpretation and petrophysical analysis were integrated to give information on the reservoir characterization of the study area for economic viability and cost effectiveness.

\section{Regional Geological Setting and Basin Evolution of the Niger Delta Basin}

The Tertiary Niger Delta lies within the coordinates of latitudes, $3^{\circ} \mathrm{N}$ and $6^{\circ} \mathrm{N}$ and longitude $5^{\circ} \mathrm{E}$ and $8^{\circ} \mathrm{E}$ [3]. The geological map of the province is illustrated in Figure 1. The basin is a product of sediments supply from rivers in the present day Niger River, Benue River and Cross River with their several distributaries flowing into the Atlantic Ocean. Sediments deposited by the rivers and distributaries consist of unlithified sand and shale forming the basin fill [12]. The Niger Delta sediments prograde southwest from Eocene to Recent to form depobelts which are the most active portion of the delta at the stage of every growth [13]. The Niger Delta depobelts formed one of the world's biggest regressive deltas within a region of some $300,000 \mathrm{~km}^{2}$, a sediment volume of 500,000 cubic kilometres and thickness of over $10 \mathrm{~km}$ [14] [15] [16]. The basin can be divided into three diachronous lithostratigraphic unit based on their stratigraphy, sedimentological, faunal data and their age. The units are Akata, Agbada and Benin Formations starting from bottom to the top [13] [17] [18]. The Akata and Agbada Formations (Tertiary) are the most prominent petroleum system in the basin [15] [19] [20]. Akata Formation comprises predominantly marine shales, with sandy and silty turbidites and continental slope channel fills while Agbada Formation predominantly consists of shoreface and channel sands at the top and an intercalation of sands and shales of equal proportion in the bottom. The Benin Formation, the youngest formation in the basin, consists of about $90 \%$ of sands and gravels derived from the continent with little shale intercalations, which becomes more abundant towards the bottom. The Akata Formation is made up of marine sediments predominantly shales and sometimes having an intercalation with the Agbada Formation. Most of the petroleum fields in the Niger Delta are either onshore or offshore located in the continental shelf with water depth of about 200 meters and relatively simple but immense geological structures. The trapping mechanisms for hydrocarbon accumulation in the 
Niger Delta are predominantly roll-over anticlines in the Agbada Formation. The prodeltaic shales in the eastern part of the Niger Delta serves as active source rocks generating hydrocarbon while the shales in the central and western parts have also contributed to hydrocarbon pooling [21].

\section{Tectonic Setting of the Niger Delta Basin}

The evolution of Niger Delta basin is related to the episodes of rifting and drifting of the African plate from the South American plates which led to the opening of the South Atlantic Ocean [22]. The rifting started and continued from the late Jurassic till mid Cretaceous and the episode is diminished in Late-Cretaceous [23]. After the Atlantic Mesozoic rift, sedimentation started with the Albian deposits. The Benue trough was filled with sediments and during the Late Eocene, the basin started prograding into the current continental slope and down to the deep sea. The continued pro-gradation of marine deposits since the Eocene extended to the current continental margin. Cretaceous fracture zones occurring as trenches and ridges in the abyssal plains of the Atlantic Ocean controlled the structural framework of the Niger Delta [24]. The ridges subdivide the continental margin of the South Atlantic Ocean into separate basins, forming the Cretaceous Benue-Abakaliki trough's border faults and cutting far into the shield of West Africa. The trough is a detached segment of a triple rift intersection linked to the evolution of the South Atlantic Ocean. A schematic diagram of a Niger Delta axial segment illustrating the connection between Tertiary fills and broken cretaceous areas is presented in Figure 2. The Niger Delta Basin extends from the south-facing coast of West Africa into the Benue Valley to the east [21]. A triple junction has been proposed to have developed at the

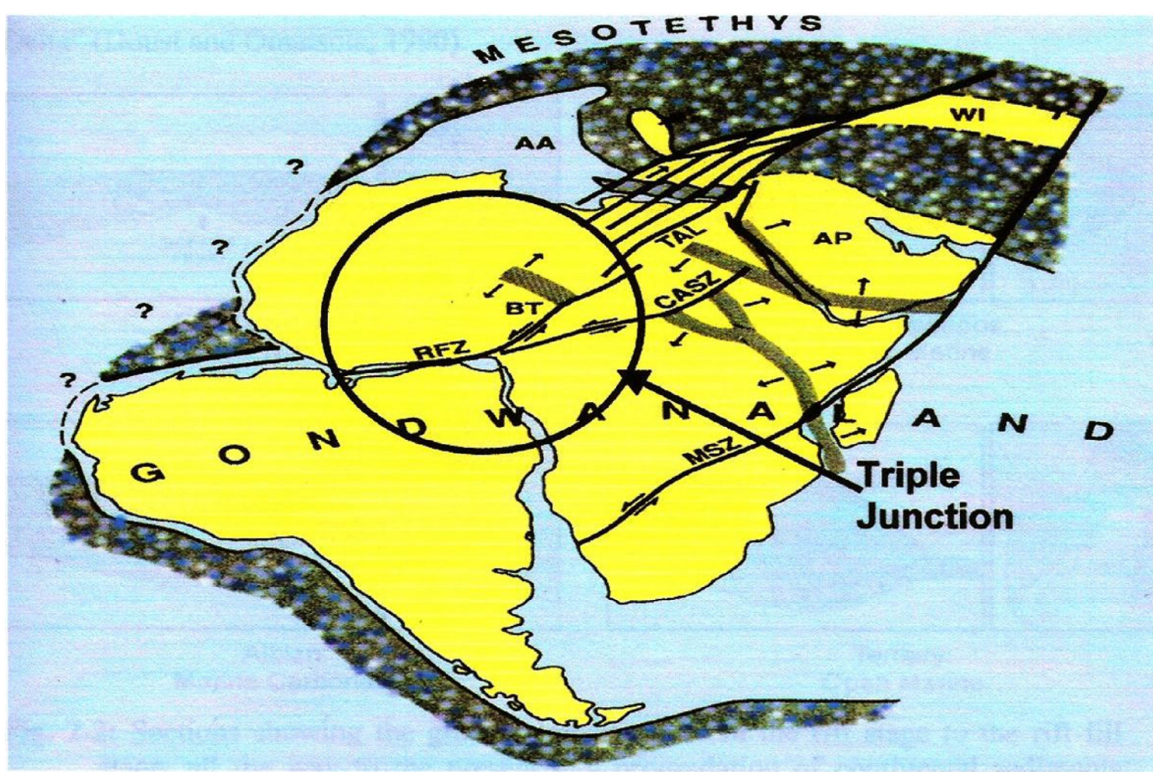

Figure 2. Breakup of Gondwanaland into Africa and South America along a triple junction in the Gulf of Guinea; the third arm failed and formed the Benue Trough. After Jev et al. [25]. 
position of what is now the outer Niger Delta. The failed arm of the triple structure is the Anambra-Benue rift valley within which oceanic crust did not develop. The African and South American continent drew apart along the ridge-transform system of the Gulf of Guinea and South Atlantic arms of the junction (Figure 2). The rivers flowing along the Benue-Anambra failed arm disgorged into a regional downwarp of the oceanic crust in the area of the triple junction. The tectonic frame work of the continental margin along the West coast of equatorial Africa is controlled by cretaceous fracture zones expressed as trenches and ridges in the deep Atlantic. The Pre-Tertiary structural framework controlled the direction and position of the progradational fill. As the pre Tertiary structural depression was filled, the depositional centres moved seawards in consequence and the coastal plain deposits became progressively younger in that direction. The Delta progrades across the narrow continental shelf and beyond the continental margin. During Oligocene-Miocene, the Delta complex had prograded southwards into deep waters and out onto the rapidly subsiding oceanic crust.

\section{Stratigraphy of the Niger Delta}

The stratigraphy of the Niger Delta can be divided into three diachronous units of Eocene to Recent age that form a major regressive cycle [17]. The uppermost unit, the Benin Formation, comprises continental/fluviatile and backswamp deposits up to $2500 \mathrm{~m}$ thick which is underlain by the Agbada Formation of paralic, brackish to marine, coastal and fluvio-marine deposits, organized into coarsening upwards "offlap" cycles. The underlying Akata Formation comprises up to $6500 \mathrm{~m}$ of marine pro-delta clays. Shales of the Akata Formation are over pressured and have deformed in response to delta progradation. These shales facilitate regional decollement for up-dip extension and down-dip compression. Shales of the Akata Formation constitute a world-class source rock. Deepwater turbidite sands also exist within this formation. The crossection of the Niger Delta is presented in Figure 3 while the correlation of subsurface formations are presented in Table 1.

\section{Methodology}

Datasets used in this study was provided by an oil and gas producing company in the region. A summary of the well log information is presented in Table 2 The dataset include: a post stacked 3D seismic survey, covering an area of 528 $\mathrm{km}^{2}$; composite log of 7 wells (AD1, AD2, AD3, AD4, AD5, AD6 and AD7) containing Laterolog-Deep Resistivity, Bulk Density, Gamma Ray, RHOB and NPHI logs. Deviation data for well AD6 and AD7 were also made available in .txt format. A check shot data from well AD1 was used to convert from time to depth across the survey. The logs used for the analysis of the wells are grouped into three categories which include lithology logs (Gamma Ray log, VSH log), resistivity logs (Res, LLD, LLS) and the porosity logs (Density (RHOB), neutron 


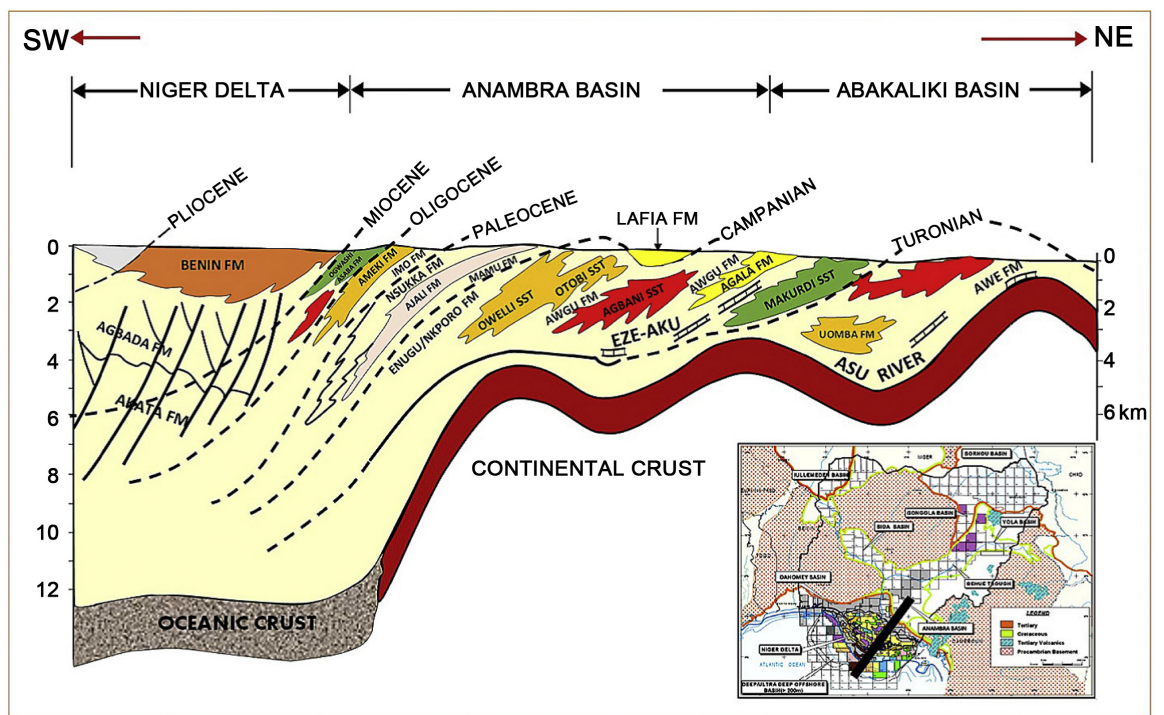

Figure 3. Cross section Niger Delta, Anambra and Abakaliliki Basins showing their lithosratigraphic unts Cross section Niger Delta. After Benkhelil [26].

Table 1. Subsurface formations in Niger Delta complex and their surface outcrops. After Short and Stauble [17].

\begin{tabular}{|c|c|c|c|c|}
\hline & & & $\begin{array}{c}\text { Surface } \\
\text { Outcrops }\end{array}$ & \\
\hline Formation & Oldest age & Youngest Age & Formation & $\begin{array}{c}\text { Oldest Known } \\
\text { age }\end{array}$ \\
\hline $\begin{array}{l}\text { Benin/Afam } \\
\text { Clay Member }\end{array}$ & Oligocene & Plio/Pleistocene & Benin & Miocene \\
\hline \multirow[t]{2}{*}{$\begin{array}{l}\text { Recent } \\
\text { Agbada }\end{array}$} & Eocene & Miocene & Ogwashi-Asaba & Oligocene \\
\hline & & Eocene & Ameki & Eocene \\
\hline \multirow[t]{3}{*}{ Recent Akata } & Eocene & L. Eocene & Imo Shale & Paleocene \\
\hline & & Palaeocene & Nsukka & Maestrichtian \\
\hline & & Maestrichtian & Ajali & Maestrichtian \\
\hline \multirow[t]{5}{*}{$\begin{array}{l}\text { Equivalent } \\
\text { not known }\end{array}$} & Cretaceous & Campanian & Mamu & Campanian \\
\hline & & Campanian/Maeastchtian & Nkporo Shale & Santonian \\
\hline & & Coniacian/Santonian & Agwu Shale & Turonian \\
\hline & & Turonian & Eze-Aku Shale & Turonian \\
\hline & & Albian & $\begin{array}{l}\text { Asu River } \\
\text { Group }\end{array}$ & Albian \\
\hline
\end{tabular}

(PHIN) and sonic (DT, 2DT). The 3D seismic survey data was used to identify the faults, horizons, boundaries and shape of the reservoirs. Petrophysical model dependent on the well log data (AD1, AD2, AD3, AD4, AD5, AD6 and AD7) were developed. The identified lithologies and shale content were used for well correlation. Estimation of the reserve was carried out with the use of the Net 
Table 2. Well log information showing the depth of the available logs (depth in $\mathrm{ft}$. .).

\begin{tabular}{cccccccccc}
\hline \multirow{2}{*}{ Wells } & \multirow{2}{*}{ TD } & \multicolumn{2}{c}{ GR (API) } & \multicolumn{2}{c}{ RES $(\mathrm{m})$} & \multicolumn{2}{c}{ NPHI (frac) } & \multicolumn{2}{c}{ RHOB $\left(\mathrm{g} \cdot \mathrm{cm}^{-1}\right)$} \\
\cline { 3 - 9 } & & Start & Stop & Start & Stop & Start & Stop & Start & Stop \\
\hline AD-1 & 12,040 & 3500 & 12,049 & 3500 & 12,049 & - & - & 3500 & 12,049 \\
AD-2 & 8461 & 2000 & 8372 & 2000 & 8372 & - & - & 2000 & 8372 \\
AD-3 & 9066 & 2000 & 9062 & 2000 & 9062 & 2000 & 9062 & 2000 & 9023 \\
AD-4 & 12,000 & 3751 & 11,978 & 3749 & 11,978 & 3949 & 11,978 & 3949 & 7898 \\
AD-5 & 9800 & 5900 & 9753 & 5900 & 9753 & 5900 & 9753 & 5900 & 9753 \\
AD-6 & 6599 & 3325 & 9924 & 3325 & 9924 & 3325 & 9924 & 3325 & 9924 \\
AD-7 & 5209 & 4991 & 10,200 & 4991 & 10,200 & 4991 & 10,200 & 4991 & 10,200 \\
\hline
\end{tabular}

Pay. Reservoir characterization was carried out to understand the geological and petrophysical characteristics of the reservoirs. The workflow used for this investigation is presented in Figure 4. The data collected were interpreted using PETREL 2013 and GeoGraphix Discovery 2013 software packages. Prior to the importation of these data into the software, the data were validated and edited to minimize error. After validation, the well log data which were in LAS data format was imported into PRISM module followed by the importation of well header information which comprises of the name, coordinates and the start and stop depths of the wells into the WELLBASE LAYER module. The post-stacked 3D seismic data were also imported into the SEISVISION module.

\section{Results}

Structural framework showing the identified growth faultsof different orientations mapped across the entire seismic survey using the Ant Tracking attribute is presented in Figure 5. Sixteen faults, labeled Flt 1 to Flt 16 were identified. The faults were observed to be elongate and generally trending East to West. Figure 6 and Figure 7, show the interpreted faults and horizons across inline 6656 and Xline 9578 respectively. The faults observed on the inline 6656 were predominantly listric growth faults, with sub parallel relationship. They illustrate an extensional collapse of the passive continental margins. Fault Flt 2 was identified as the major synthetic active growth fault controlling the field. Roll over anticlines were formed as a result of the deformation of the sediments deposited at the downthrown block of the major faults Flt1, Flt2 and Flt3 (Figure 6). The reservoirs in the seismic survey were observed to be roll over anticline structures, bounded by the closure of the two major synthetic faults which provided the structural dip closure (trap) responsible for the accumulation of hydrocarbon in the field. The syndepositional roll over anticlines identified at the downthrow of faults Flt1, Flt2 and Flt3 have developed during sedimentation with each layer of the sediments showing thickens towards the direction of faults (Figure 6). The wells in this study were drilled to target the downthrown of fault Flt2. The fault Flt 2 cuts through the entire mapped area and Flt3 forms a dip closure on the eastern portion of the survey and trends south west to the middle of the seismic survey. 


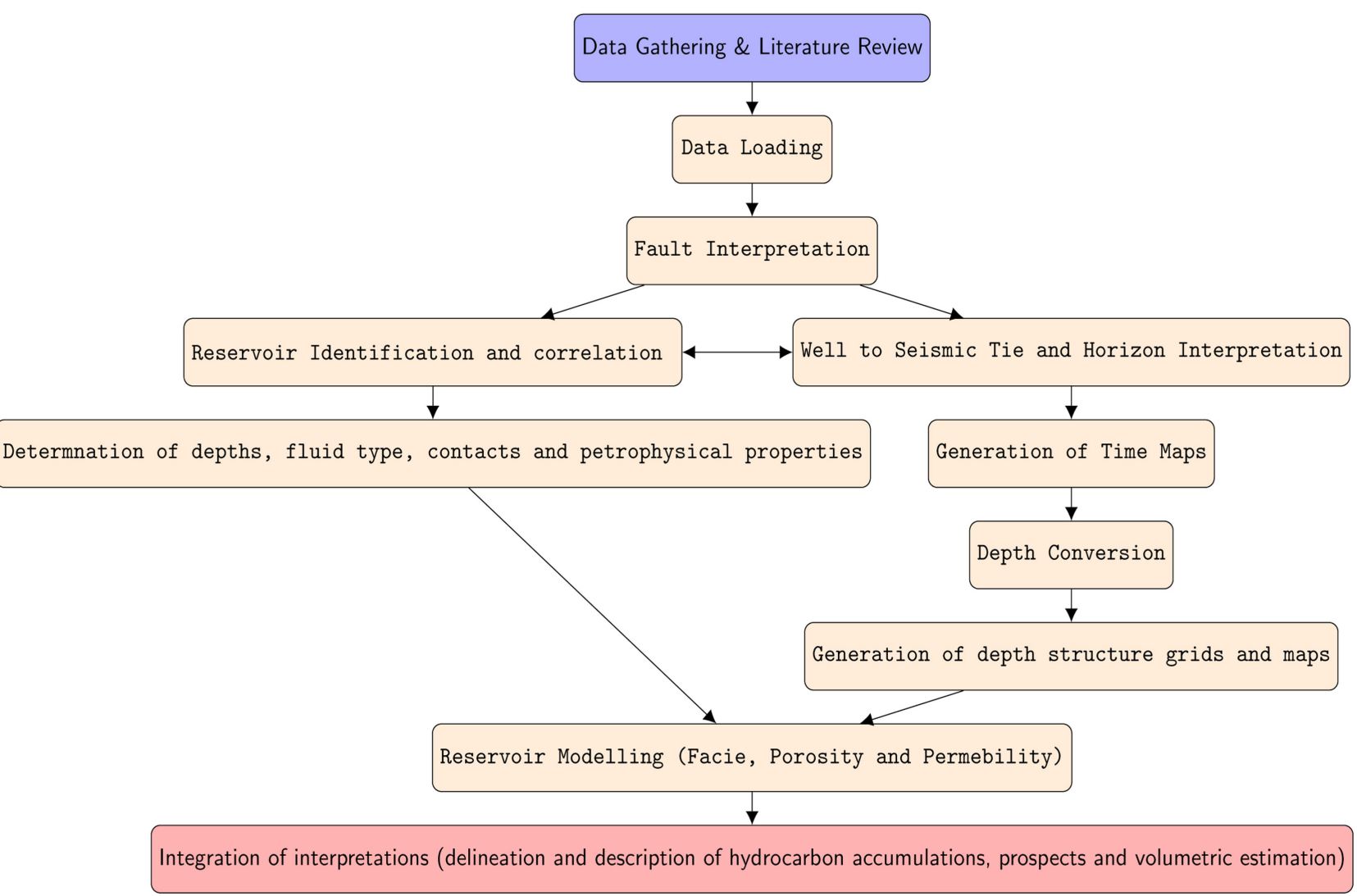

Figure 4. Workflow for volumetric analysis of the AD Field.

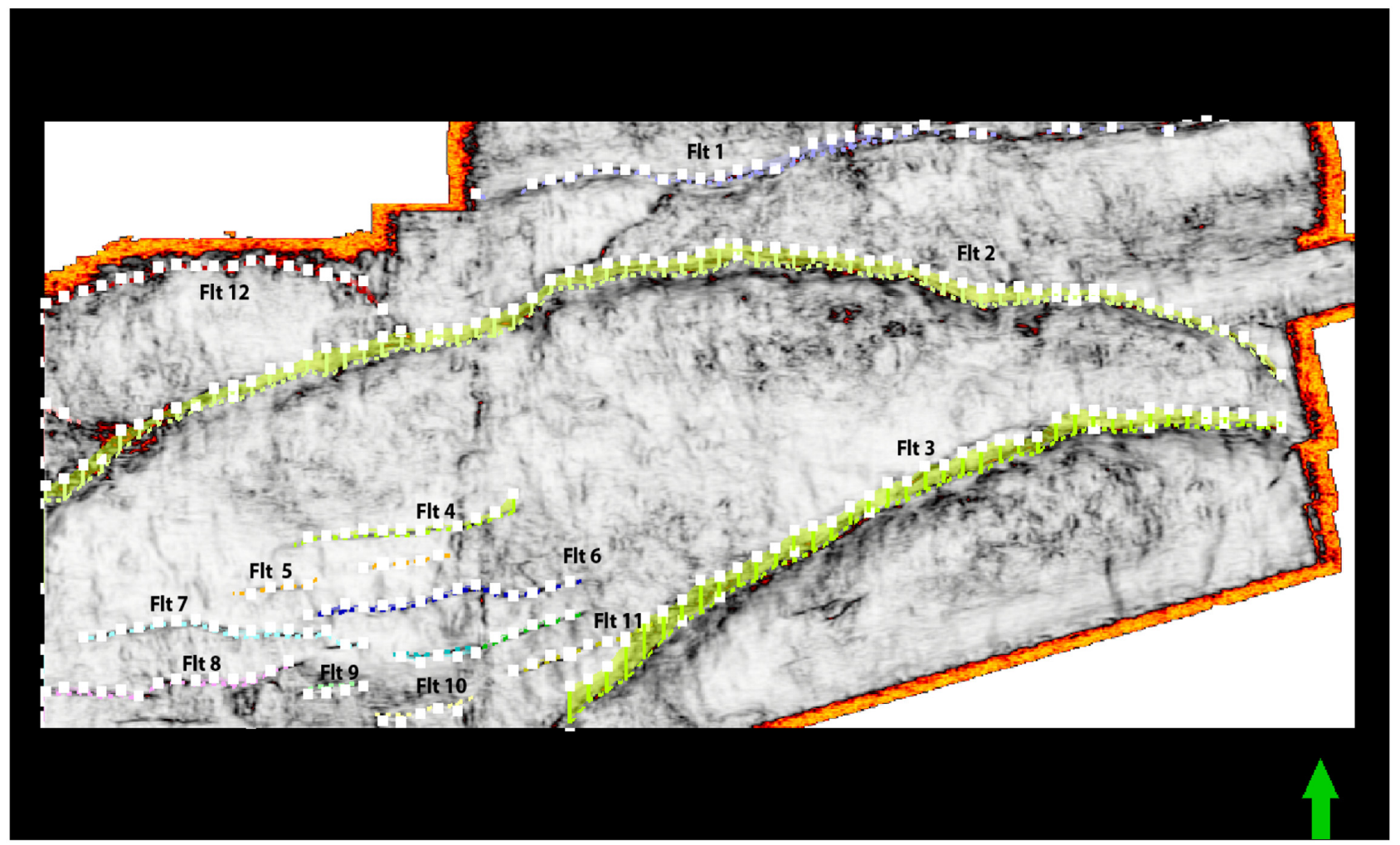

Figure 5. Structural framework of AD Field. 


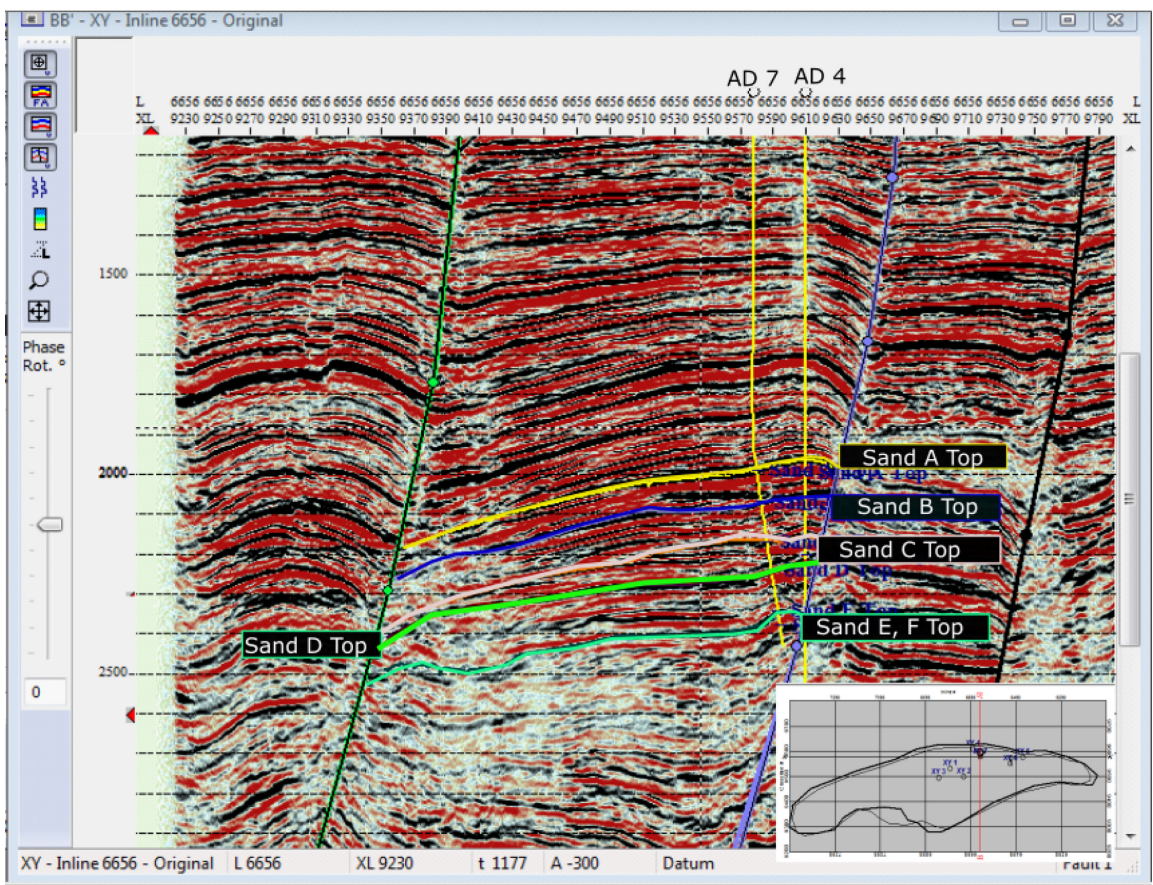

Figure 6. Interpreted faults and horizons across on inline 6656.

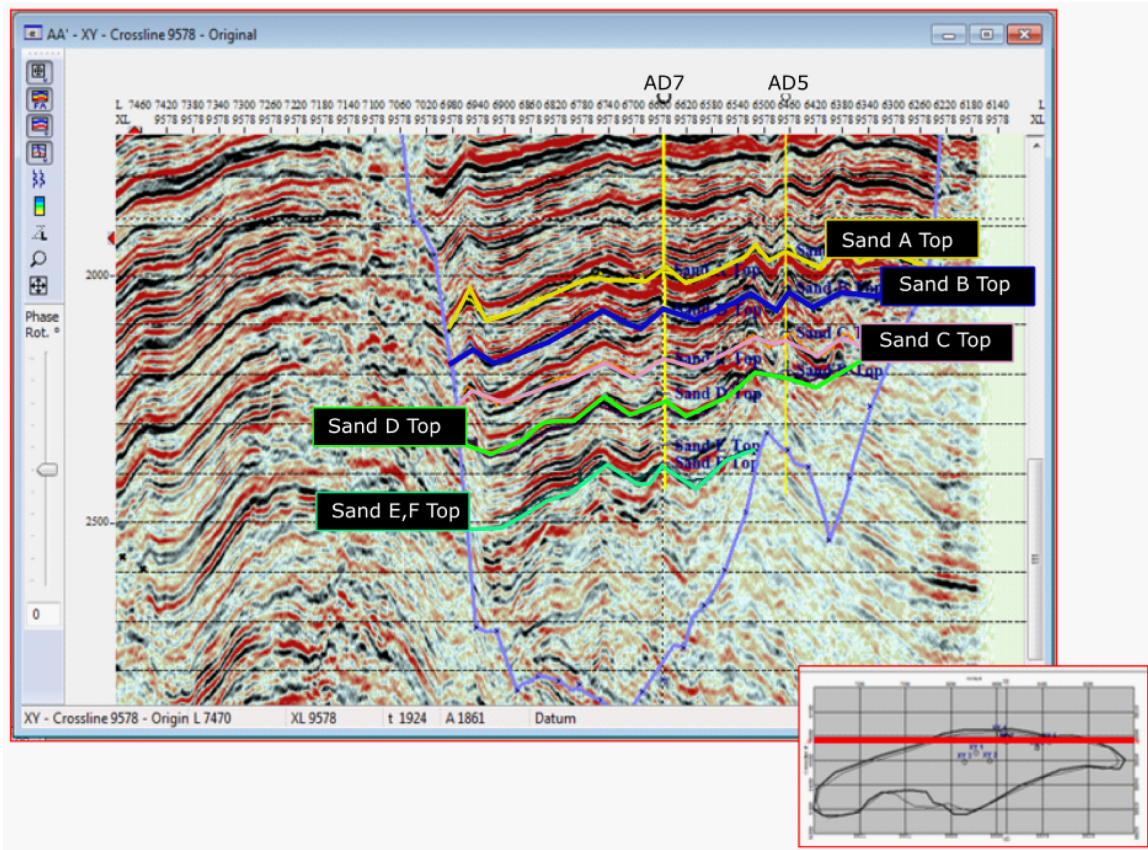

Figure 7. Interpreted faults and horizons across on Xline 9578.

\subsection{Well Correlation Log Facies and Depositional Environment}

Seven wells were correlated across the field using the GR and Resistivity logs to give a good description of the reservoirs and to determine the lateral continuity of the sand intervals. The correlation chart and cross-section of the wells from East to West in the following order: $\mathrm{AD} 3, \mathrm{AD} 1, \mathrm{AD} 2, \mathrm{AD} 4, \mathrm{AD} 7$, and $\mathrm{AD} 6$ to AD5 are shown in Figure 8. Six sand intervals which serve as reservoirs within 


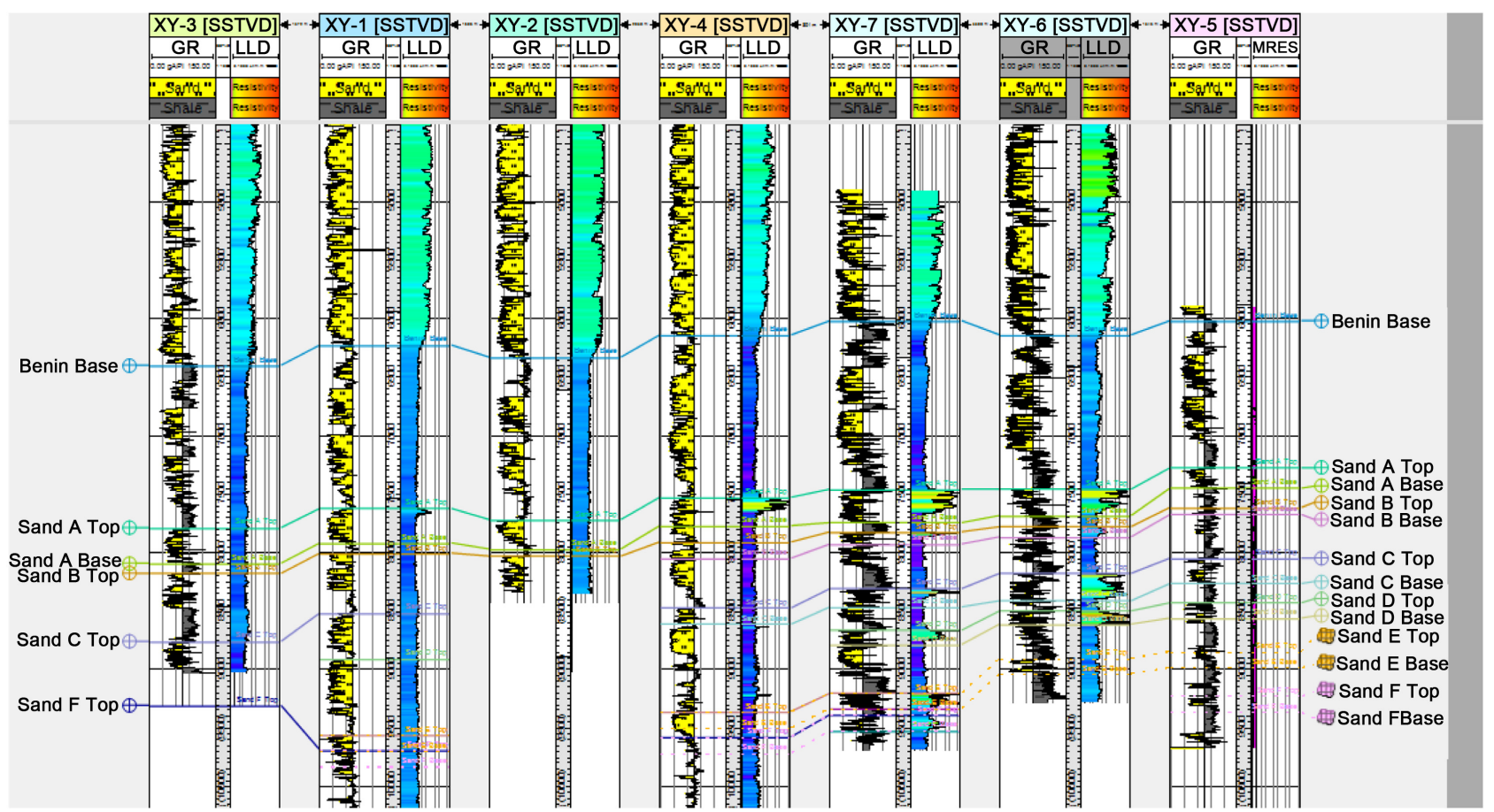

Figure 8. West-East correlation of hydrocarbon bearing sand across wells in the AD Field.

the Agbada Formation, were identified and labeled as Sand A, B, C, D, E and F. The sand intervals were observed to thin towards the basin from the North to the South suggesting a prograding sequence. Several publications have reported the determination of depositional environment from log shapes [27] [28]. The GR log pattern was used to correlate the horizons across the AD Fields, (Figure 8). The sand intervals observed in the wells vary from blocky to ratty sand. A quick look evaluation of the log facies of the gamma ray logs across the Field showed that the Benin Formation is characterized by blocky sands with a combination of serrated and cylindrical patterns diagnostic of deltaic progradation and river flood plains [29]. Agbada Formation was identified with ratty sands on well logs with intercalation of sands and shales of point bars of a distributary channel fills, coastal barriers and shore face deposits [29].

\subsection{Horizon Interpretation and Reservoir Description}

In order to understand the subsurface geology and structural trend for possible hydrocarbon accumulation, seismic and well data were tied. Based on the seismic to well ties, six major horizons were identified, picked and interpreted across the seismic volume. The six hydrocarbon bearing sand units within the Agbada Formation labeled Sand A to F were mapped within the seismic section. Contour maps showing the most accurate representative geology of Sand A, B and $\mathrm{C}$ are presented as both time (Isochron) maps and depth (Isopach) maps in Figures 9-11. The maps show the two major faults (Flt2 and Flt3) that formed the closure responsible for the hydrocarbon accumulation in the Field. Both time and depth structure map of Sand A reservoir is presented in Figure 9. The depth 


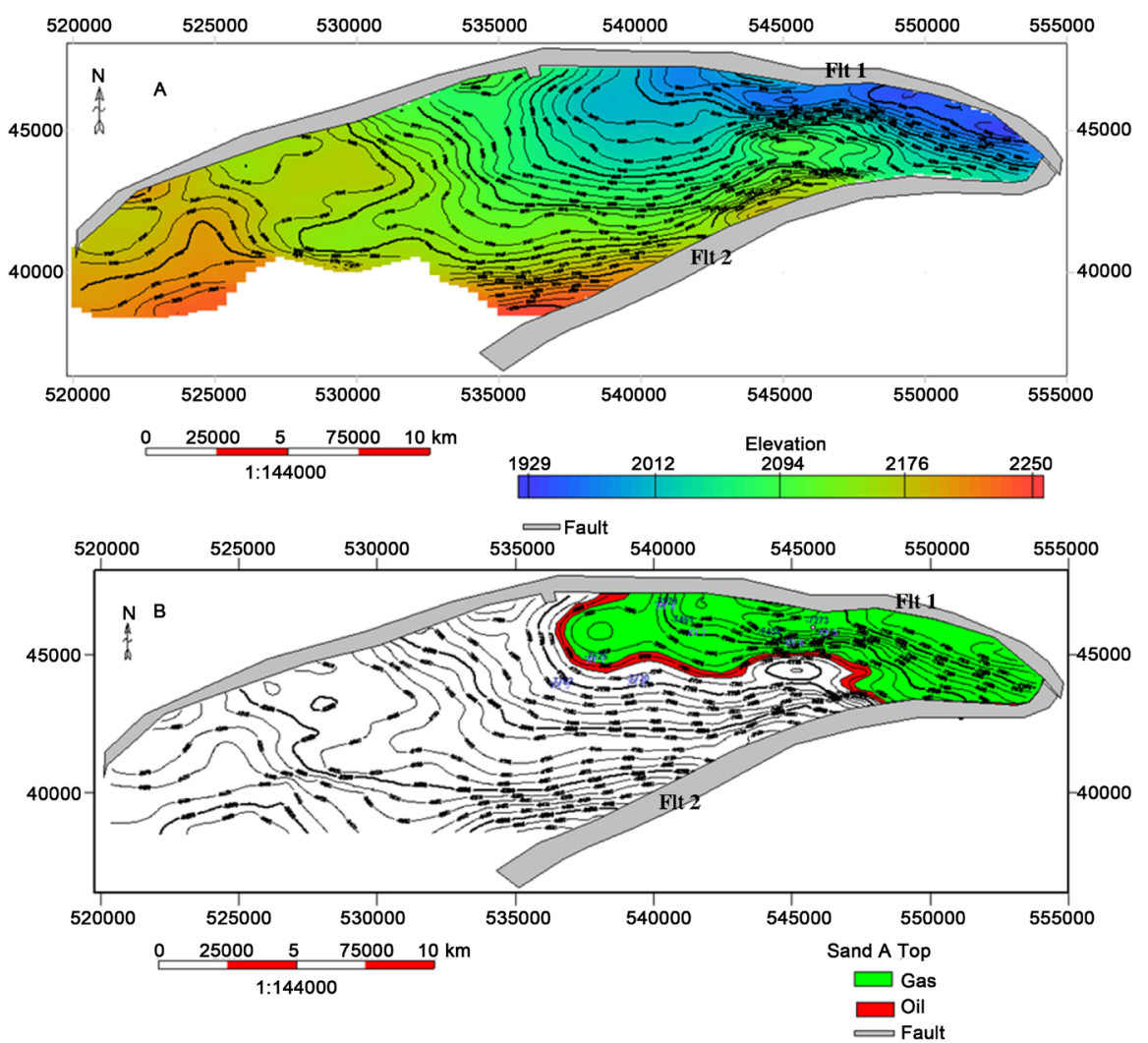

Figure 9. Time and depth structure map of sand a showing accumulation of oil and hydrocarbon prospect at the closure between Flt2 and Flt3.

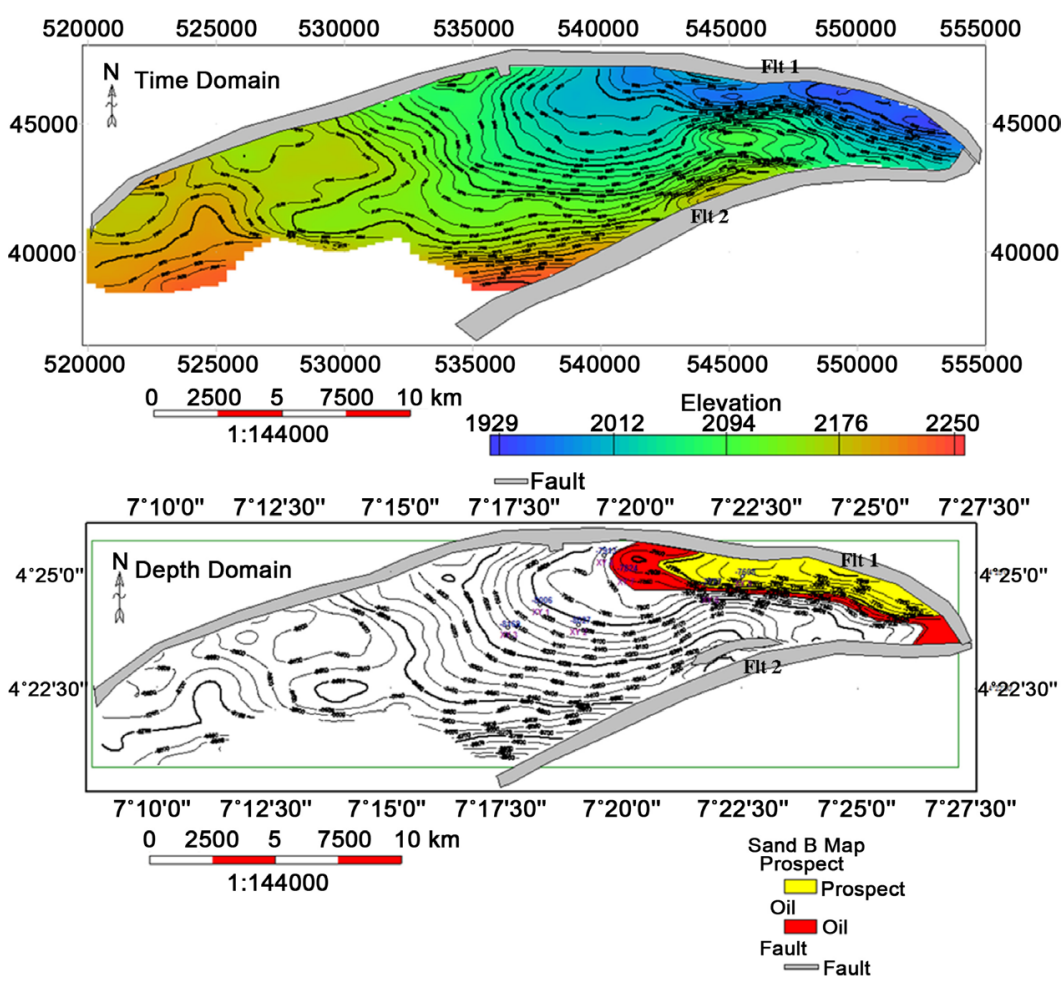

Figure 10. Time and depth structure map of sand B showing accumulation of oil and hydrocarbon prospect at the closure between Flt2 and Flt3. 


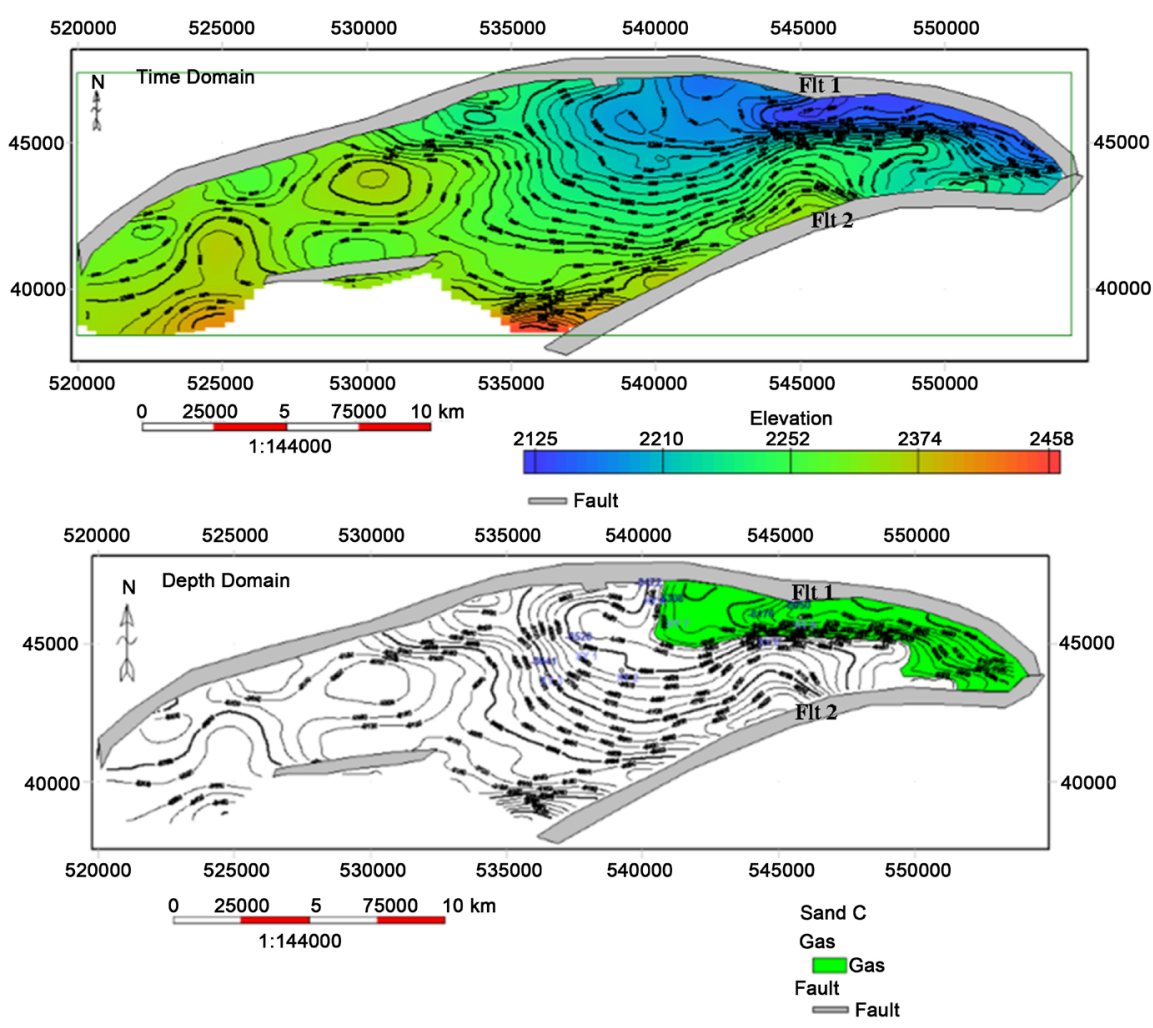

Figure 11. Time and depth structure map of Sand C showing accumulation of gas at the closure between Flt2 and Flt3.

map has contour lines varying from $-7413.73 \mathrm{ft}$. to TVDSS of $-7683.75 \mathrm{ft}$. with an average gross interval of $270.02 \mathrm{ft}$ across the wells. The lowest point on the map is along the north-eastern portion. Flt2 and Flt3 were identified as the two major faults forming the structural closure responsible for hydrocarbon accumulation in the Field. Four wells AD4, AD5, AD6 and AD7 were placed to have been situated to target both oil and gas in the reservoir. The time and depth structure map of Sand B reservoir is presented in Figure 10. The depth map varied from $-7778 \mathrm{ft}$. to TVDSS of $-7878 \mathrm{ft}$. with an average gross interval of $59 \mathrm{ft}$. across the wells. The lowest point on the map is located along the north-eastern portion. Flt2 and Flt3 were identified as the two major faults forming the structural closure responsible for hydrocarbon accumulation in the Field. Two wells AD6 and AD7 were observed to have been situated to target both oil and other hydrocarbon prospect the reservoir. The time and depth structure map of Sand $\mathrm{C}$ reservoir is presented in Figure 11. The depth map has contour lines varying from $-8176 \mathrm{ft}$. to TVDSS of $-8624 \mathrm{ft}$. with an average gross interval of $299 \mathrm{ft}$. across the wells. The lowest point on the map is along the north-eastern portion.

\subsection{Reservoir Properties of AD Field}

The pay summary of the reservoirs, especially porosity, permeability and Net to Gross in the AD Field is presented in Table 3. The Net to Gross ratio (NTG) ranges between 0.79 and 0.87 , while the porosity varies from $20 \%$ to $28 \%$ and 
Table 3. Reservoir depths and fluid contacts across the AD Field (ft.).

\begin{tabular}{|c|c|c|c|c|c|c|c|c|c|c|}
\hline Reservoirs & Well & Top MD & Base MD & $\begin{array}{c}\text { Gross } \\
\text { Interval }\end{array}$ & Net Res & Net Pay & GOC & OWC & GDT & ODT \\
\hline \multirow[t]{4}{*}{ Sand A } & $\mathrm{AD} 4$ & -7477.71 & -7859.68 & 381.97 & 360.57 & 109.49 & -7627 & -7667 & & \\
\hline & AD 5 & -7272.71 & -7446.67 & 173.96 & 135.53 & 59.85 & & & -7447 & \\
\hline & $\mathrm{AD} 6$ & -7451.31 & -7693.91 & 242.60 & 190.21 & 138.03 & -7620 & -7656 & & \\
\hline & $\mathrm{AD} 7$ & -7453.20 & -7734.74 & 281.54 & 273.48 & 192.71 & -7630 & -7661 & & \\
\hline \multirow[t]{2}{*}{ Sand B } & $\mathrm{AD} 6$ & -7777.46 & -7840.77 & 63.32 & 38.51 & 19.17 & & & & -7840 \\
\hline & $\mathrm{AD} 7$ & -7824.06 & -7878.87 & 54.81 & 53.71 & 28.84 & & & -7860 & \\
\hline \multirow[t]{2}{*}{ Sand C } & $\mathrm{AD} 6$ & -8176.21 & -8459.57 & 283.36 & 211.21 & 146.53 & -8384 & & & \\
\hline & $\mathrm{AD} 7$ & -8308.47 & -8624.11 & 315.65 & 276.72 & 43.68 & -8384 & & & \\
\hline \multirow[t]{2}{*}{ Sand D } & $\mathrm{AD} 6$ & -8497.07 & -8740.84 & 243.77 & 180.87 & 75.02 & -8617 & & & \\
\hline & $\mathrm{AD} 7$ & -8661.62 & -9010.60 & 348.98 & 326.07 & 78.35 & -8683 & -8752 & & \\
\hline Sand E & $\mathrm{AD} 7$ & -9202.28 & -9342.91 & 140.64 & 121.97 & 106.02 & -9299 & -9340 & & \\
\hline Sand $\mathrm{F}$ & $\mathrm{AD} 7$ & -9390.83 & -9528.34 & 137.55 & 116.84 & 65.18 & & & -9504 & \\
\hline
\end{tabular}

can be quantitatively evaluated as very good [29]. These values are similar with what has been reported for Niger Delta, ranges from 15\% - 40\% in the reservoir rocks and below waht was proposed by Edwards and Santogrossi [30] (40\%) for primary Niger Delta Miocene paralic sandstones reservoirs. The computed porosity of Sand A to F reservoirs vary between 0.19 and 0.32 (avg. 0.29) indicating a good to excellent reservoir characteristics [29] and were also observed to reduce with depth with Sand A (26\%) and Sand B (28\%) having the highest porosity while Sand F $(0.20 \%)$ have the lowest. The thickness of the reservoirs varies laterally and they are controlled by the growth faults. The net pay thickness across the field varied with depths between $59 \mathrm{ft}$. and $192 \mathrm{ft}$ (avg. $125 \mathrm{ft}$.). The Gross Rock Volume (GRV) for each of the six reservoirs was computed from the volume within reservoir polygons and fluid contacts within the reservoirs. The GRV for gas and oil in the entire field were computed as 266.33 (acre foot) and 180.21 (acre foot) respectively. The water saturation ( $\mathrm{Sw}$ ) in the field ranges from 0.19 to 0.39 with Sand A (0.19) having the lowest water saturation. The total STOIIP and GIIP from the field was estimated as $565 \mathrm{mmbl}$ and $4.08 \mathrm{tcf}$ respectively. Sand A was reported the most economic and viable interval with 39\% of the STOIIP and $46 \%$ of GIIP in the AD Field.

\subsection{Static Reservoir Modelling}

The static reservoir model of Sand A, the highest hydrocarbon potential, was developed to give a fair reality of the subsurface. The Sand A reservoir was used because it extends across all the studied wells representing the reservoir with the greatest hydrocarbon accumulation in the field. Structural and stratigraphic modelling of Sand A reservoir is presented in Figure 12. 


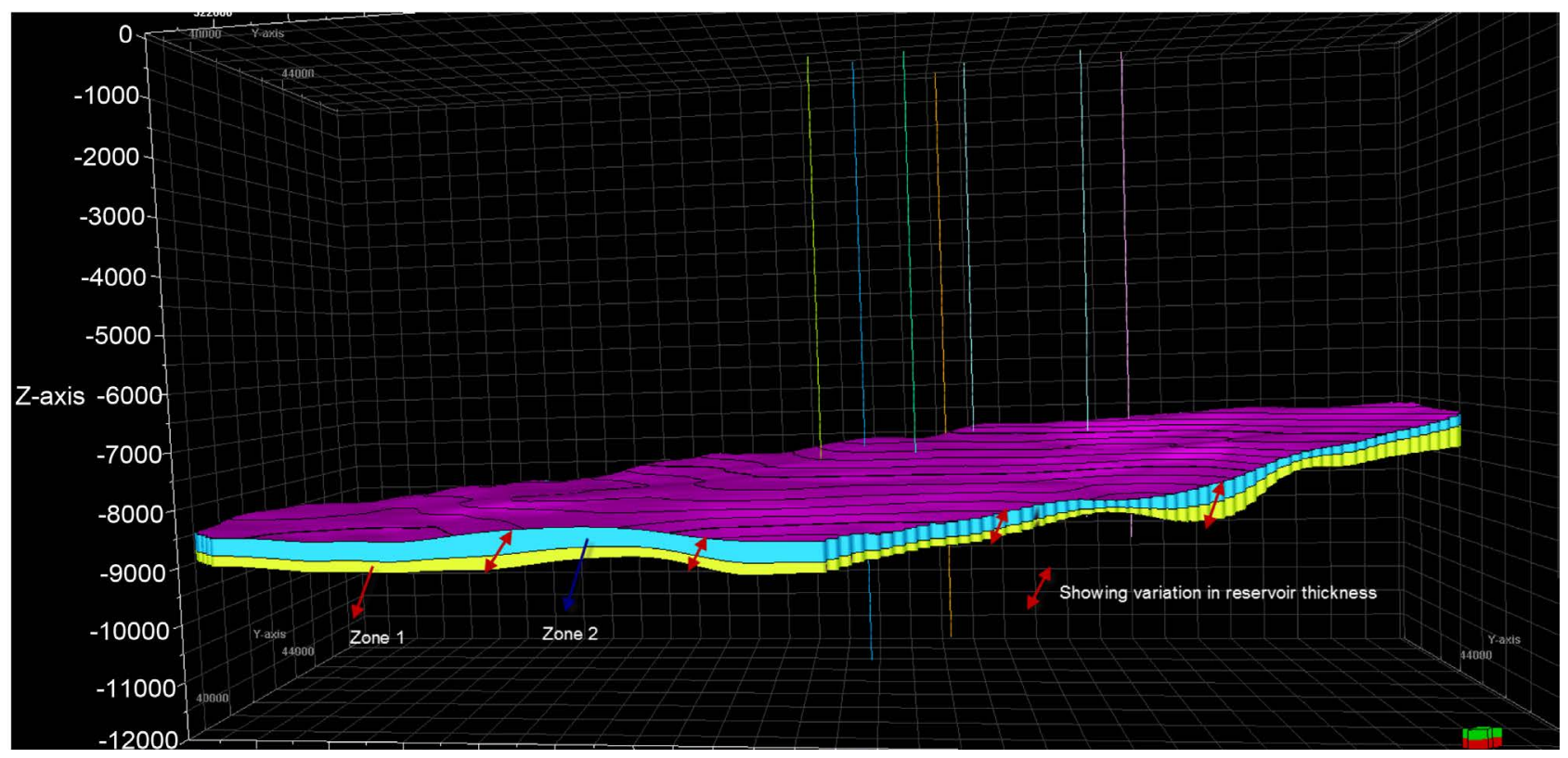

Figure 12. Structural and stratigraphic modeling of Sand A.

\subsubsection{Porosity Model of Sand A}

A 3D porosity model showing the porosity distribution in the Sand A reservoir is presented in Figure 13. The porosity model shows well distributed porosity within the field and range from 0.10 to 0.42 . However about $90 \%$ of the data have porosity ranging between 0.20 and 0.42 which indicates good to excellent porosity (pore spaces) capable of retaining hydrocarbon. Wells in the eastern portion (AD4, AD5, AD6 and AD7) falls within the region with very good reservoir characteristics with average porosity between 0.26 and 0.32 .

\subsubsection{Water Saturation Model of Sand A}

The water saturation model for Sand A reservoir (Figure 14) shows water saturation from 0.2 to 0.9 . The south-eastern part reported water saturation greater than 0.75 indicating high accumulation of water. However, the north-eastern part of the model shows grids of water saturation with values between 0.2 and 0.5 which is indicative of hydrocarbon zones in the reservoir. The hydrocarbon producing wells in the Field (AD4, AD5, AD6 and AD7) were situated in this part of the model.

\subsubsection{Facie Model}

The facie model of Sand A reservoir Figure 15 shows that all the facies have a regional distribution pattern with a North-South orientation composed of shale (30\%), fine sand (60\%) and coarse sands (10\%). The abundance of shale in the reservoir indicates a transgressive marine environment with minor influence of tides in marine condition [31].

\subsubsection{Reservoir Volumetric}

The volumetric estimates after modelling Sand A reservoir is presented in Table 4 which shows that the sand interval has a gross thickness ranging between 173 

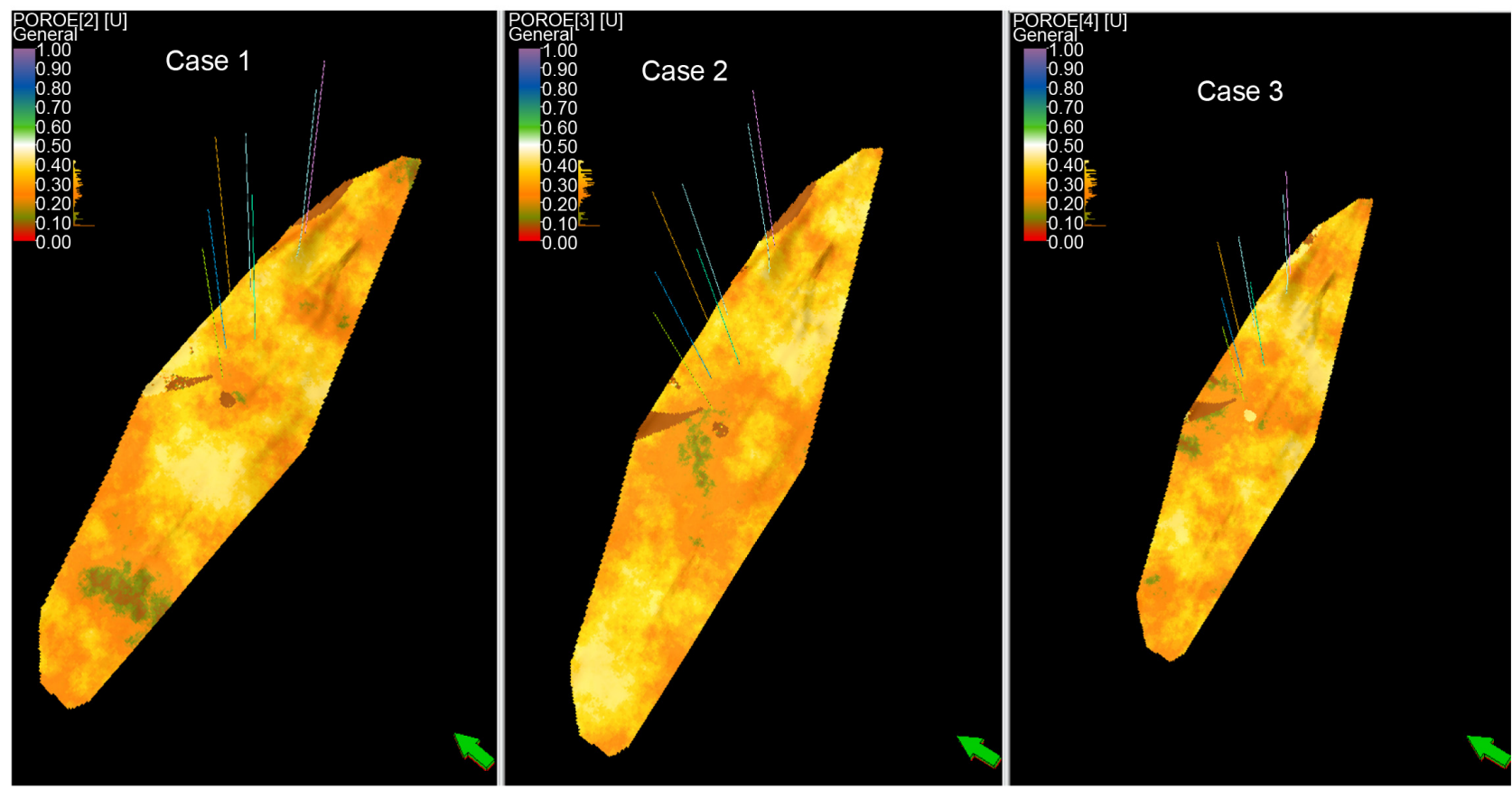

Figure 13. Porosity model for Sand A showing the distribution of the wells.
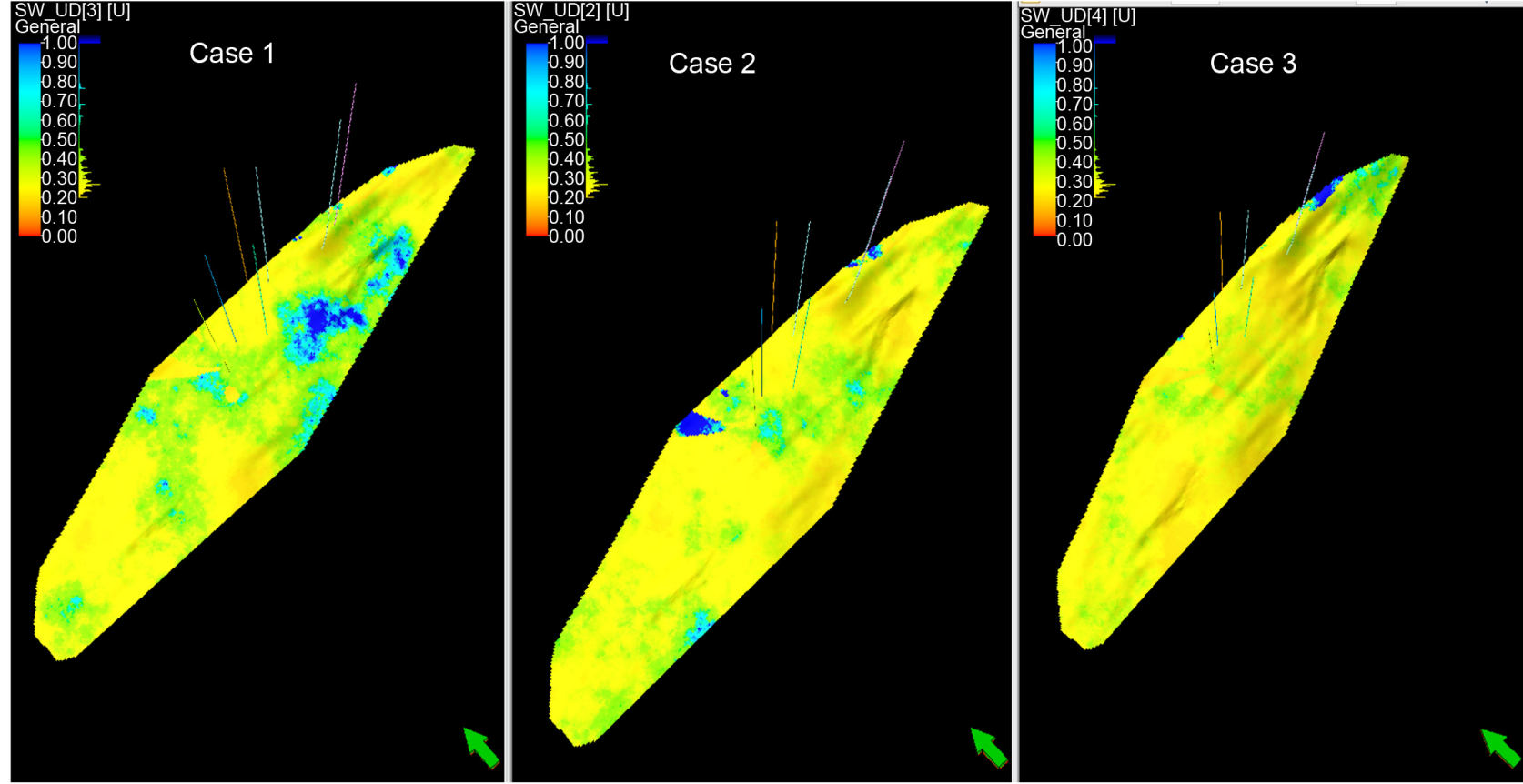

Figure 14. The trend of water saturation in the reservoir showing the distribution of the wells.

$\mathrm{ft}$. and $381 \mathrm{ft}$. The reservoir has a total pore volume of $2343 \times 10^{6} \mathrm{RB}$ with $9 \%$ Hydrocarbon Pore Volume (HCPV) oil of $209 \times 10^{6} \mathrm{RB}$ and $56 \%$ Hydrocarbon Pore Volume (HCPV) gas of $1314 \times 10^{6} \mathrm{RB}$. The reservoir has a STOIIP of $175 \times$ $10^{6}$ STB and GIIP of $438,096 \times 10^{6} \mathrm{MSCF}$, which indicates that the hydrocarbon in Sand $\mathrm{A}$ is of commercial value and the static model derived from it could be used for simulation and monitoring performance. 


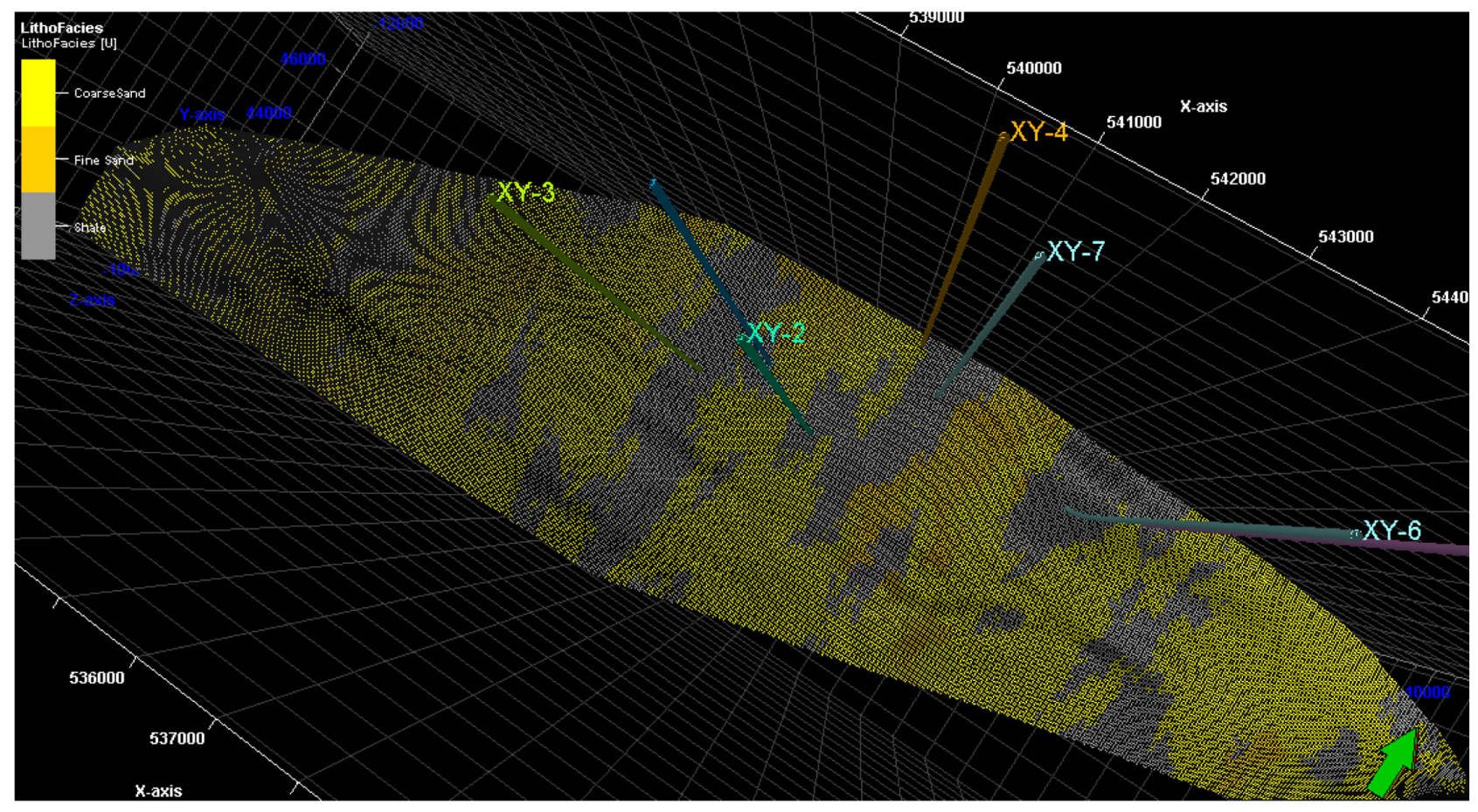

Figure 15. Facie model for Sand A reservoir showing the distribution of coarse sand, fine sand and shale.

Table 4. Volumetric estimate obtained from Sand A after modeling.

\begin{tabular}{cc}
\hline & Zone 1 \\
\hline Bo (formation Vol. factor) & 1.2 \\
Recovery factor & 0.35 \\
Pore volume & $2343 \times 10^{6} \mathrm{RB}$ \\
HCPV oil & $209 \times 10^{6} \mathrm{RB}$ \\
HCPV gas & $1314 \times 10^{6} \mathrm{RB}$ \\
STOIIP (in oil) & $175 \times 10^{6} \mathrm{STB}$ \\
GIIP (in gas) & $438,096 \times 10^{6} \mathrm{MSCF}$ \\
Recoverable oil & $61 \times 10^{6} \mathrm{STB}$ \\
Recoverable gas & $306,667 \times 10^{6} \mathrm{MSCF}$ \\
\hline
\end{tabular}

\subsection{Uncertainty Analysis}

The influences of uncertain geologic parameters including saturation $\left(S_{w}\right)$, Porosity $(\rho)$, NTG and GRV on the STOIIP were identified and quantified using deterministic values and the summary result of the P10, P50 and P90 after Monte Carlo simulation for the field is presented in (Table 5). The influence of the geological parameters on the STOIIP was and graphically displayed on the Tornado charts presented in Figure 16. The Tornado diagrams graphically represent the result of the sensitivity. The length of the bars on the Tornado diagram or represents the regression coefficient and the influence of the input (geologic parameters) on the output STOIIP. A positive coefficient with bars towards the right indicates that the geologic parameters have a positive impact 
Table 5. Percentile ranking after P10, P50 and P90 after Monte Carlo simulation for AD Field.

\begin{tabular}{ccccccc}
\hline Percentile & Sand A & Sand C & Sand D & Sand E & Sand F & TOTAL \\
\hline 5 & 1.53 & 1.11 & 0.45 & 0.45 & 0.15 & 3.69 \\
10 & 1.59 & 1.15 & 0.46 & 0.46 & 0.16 & 3.82 \\
15 & 1.63 & 1.17 & 0.47 & 0.47 & 0.16 & 3.92 \\
20 & 1.67 & 1.19 & 0.48 & 0.48 & 0.16 & 3.99 \\
25 & 1.71 & 1.21 & 0.49 & 0.49 & 0.17 & 4.07 \\
30 & 1.73 & 1.23 & 0.50 & 0.50 & 0.17 & 4.13 \\
35 & 1.76 & 1.24 & 0.50 & 0.50 & 0.17 & 4.19 \\
40 & 1.79 & 1.26 & 0.51 & 0.51 & 0.17 & 4.24 \\
45 & 1.82 & 1.27 & 0.52 & 0.52 & 0.18 & 4.3 \\
50 & 1.85 & 1.29 & 0.52 & 0.52 & 0.18 & 4.35 \\
55 & 1.87 & 1.30 & 0.53 & 0.53 & 0.18 & 4.41 \\
60 & 1.90 & 1.32 & 0.54 & 0.53 & 0.18 & 4.47 \\
65 & 1.93 & 1.33 & 0.54 & 0.54 & 0.18 & 4.52 \\
70 & 1.96 & 1.35 & 0.55 & 0.55 & 0.19 & 4.59 \\
75 & 1.99 & 1.37 & 0.56 & 0.56 & 0.19 & 4.66 \\
80 & 2.03 & 1.39 & 0.57 & 0.57 & 0.19 & 4.74 \\
85 & 2.07 & 1.41 & 0.58 & 0.58 & 0.20 & 4.83 \\
90 & 2.13 & 1.44 & 0.59 & 0.59 & 0.20 & 4.95 \\
95 & 2.21 & 1.49 & 0.61 & 0.61 & 0.21 & 5.12 \\
\hline
\end{tabular}

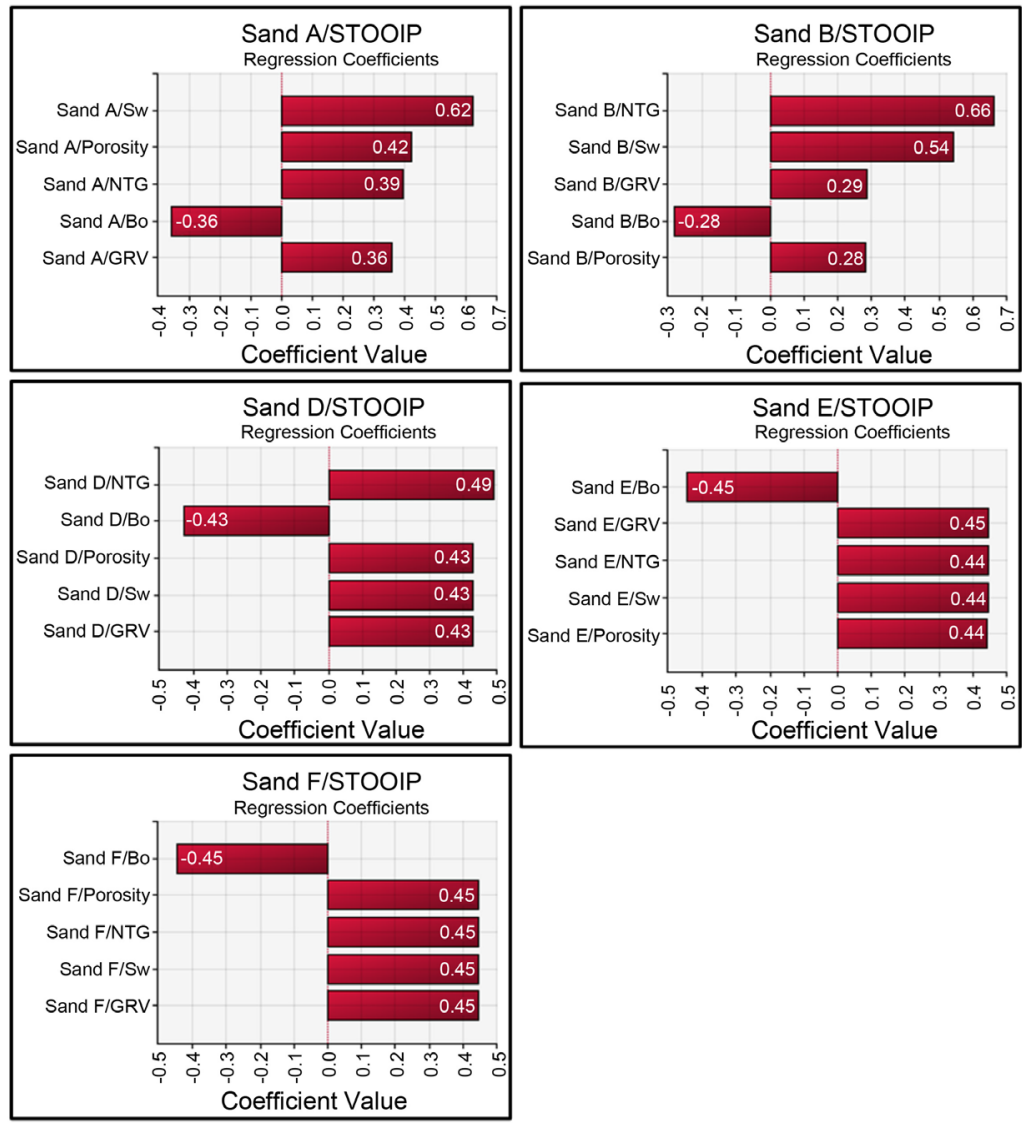

Figure 16. Tornado charts graphically showing the sensitivity of geological parameter on the STOIIP values. 
such that there is increase in the output value. A negative coefficient with bars extending to the left indicates the geologic parameter has a negative impact such that an increase in the geologic parameter will decrease the output value. Water of saturation (Sw) and the net to gross ratio (NTG) were observed to have the greatest influence on the STOIIP estimates.

\section{Summary and Conclusion}

The hydrocarbon resource in AD field, Niger Delta of Nigeria was evaluated by calculating the Hydrocarbon initially in place using both deterministic and stochastic techniques. The stochastic evaluation was carried out by subjecting the deterministic results to Monte Carlo simulation in order to quantify the influence of the petrophysical parameters on the HIIP and identify the P10, P50 and P90 values for the reservoirs in the field. Sixteen faults labelled Flt 1 to Flt 16 were identified and mapped across the survey during seismic interpretation. Two major faults (Flt 1 and Flt 2) were identified as the major structure building faults responsible for inducing a major structural trap (fault induced closure) at the western part of the survey. The fault closure is responsible for the accumulation of hydrocarbon in the field. The faults observed in the study are predominantly listric normal faults which extensional regimes peculiar with the Niger Delta Basin.

\section{Conflicts of Interest}

The authors declare no conflicts of interest regarding the publication of this paper.

\section{References}

[1] Nwajide, C.S. (2013) Geology of Nigeria's Sedimentary Basins. CSS Bookshops Limited, Lagos.

[2] Tuttle, M.L., Charpentier, R.R. and Brownfield, M.E. (1999) The Niger Delta Petroleum System: Niger Delta Province, Nigeria, Cameroon, and Equatorial Guinea, Africa. US Department of the Interior, US Geological Survey. https://doi.org/10.3133/ofr9950H

[3] Reijers, T.J.A. (1996) Selected Chapters on Geology: Sedimentary Geology and Sequence Stratigraphy in Nigeria, Three Case Studies and a Field Guide. Shell Petroleum Development Corporation. Corporate Reprographic Services, Warri.

[4] Corredor, F., Shaw, J.H. and Bilotti, F. (2005) Structural Styles in the Deepwater Fold and Thrust Belts of the Niger Delta. Bulletin-American Association of Petroleum Geologists, 89, 753-780. https://doi.org/10.1306/02170504074

[5] Fajana, A.O., Ayuk, M.A., Enikanselu, P.A. and Oyebamiji, A.R. (2019) Seismic Interpretation and Petrophysical Analysis for Hydrocarbon Resource Evaluation of "Pennay" Field, Niger Delta. Journal of Petroleum Exploration and Production Technology, 9, 1025-1040. https://doi.org/10.1007/s13202-018-0579-4

[6] Egbai, J.C., Atakpo, E. and Aigbogun, C.O. (2012) Predictive Deconvolution in Seismic Data Processing in Atala Prospect of Rivers State, Nigeria. Advances in Applied Science Research, 1, 520-529. 
[7] Sessions, K.P. and Lehman, D.H. (1989) Nurturing the Geology-Reservoir Engineering Team: Vital for Efficient Oil and Gas Recovery. SPE Annual Technical Conference and Exhibition, San Antonio, October 1989, SPE-19780-MS. https://doi.org/10.2118/19780-MS

[8] Garb, F.A. (1988) Assessing Risk in Estimating Hydrocarbon Reserves and in Evaluating Hydrocarbon-Producing Properties (Includes Associated Papers 18606 and 18610). Journal of Petroleum Technology, 40, 765-778.

https://doi.org/10.2118/15921-PA

[9] Caldwell, R.H. and Heather, D.I. (1991) How to Evaluate Hard-to-Evaluate Reserves. Journal of Petroleum Technology, 43, 998-1003.

https://doi.org/10.2118/22025-PA

[10] Rui, Z., Lu, J., Zhang, Z., Guo, R., Ling, K., Zhang, R. and Patil, S. (2017) A Quantitative Oil and Gas Reservoir Evaluation System for Development. Journal of Natural Gas Science and Engineering, 42, 31-39.

https://doi.org/10.1016/j.jngse.2017.02.026

[11] Odai, L.A. (2010) Building and Ranking of Geostatistical Petroleum Reservoir Models. Doctoral Dissertation.

[12] Idowu, J.O., Ajiboye, S.A., Ilesanmi, M.A. and Tanimola, A. (1993) Origin and Significance of Organic Matter of Oshosun Formation, Southwestern Dahomey Basin. Nigeria Journal of Mining and Geology, 29, 9-17.

[13] Doust, H. and Omatsola, E. (1990) Niger Delta. In: Edwards, J.D. and Santogrossi, P.A., Eds., Divergent/ Passive Margin Basins, AAPG Memoir 48, American Association of Petroleum Geologist, Tulsa, 239-248.

[14] Hospers, J. (1965) Gravity Field and Structure of the Niger Delta, Nigeria. West Africa Geological Society of American Bulletin, 76, 407-422. https://doi.org/10.1130/0016-7606(1965)76[407:GFASOT]2.0.CO;2

[15] Kulke, H. (1995) Nigeria. In: Kulke, H., Ed., Regional Petroleum Geology of the World. Part II: Africa, America, Australia and Antarctica, Gebrüder Borntraeger, Berlin, 143-172.

[16] Kaplan, E.L. and Meier, P. (1958) Nonparametric Estimation from Incomplete Observations. Journal of the American Statistical Association, 53, 457-481. https://doi.org/10.1080/01621459.1958.10501452

[17] Short, K.C. and Stauble, A.J. (1967) Outline of Geology of Niger Delta. AAPG Bulletin, 51, 761-779. https://doi.org/10.1306/5D25C0CF-16C1-11D7-8645000102C1865D

[18] Weber, K.J. and Daukoru, E.M. (1975) Petroleum Geology of the Niger Delta. Proceeding of the Ninth World Petroleum Congress, Tokyo, Vol. 2, 209-221.

[19] Evamy, B.D., Harembourne, J., Kermerling, P., Knapp, W.A., Molloy, F.A. and Rowlands, P.H. (1978) Hydrocarbon Habitat of Tertiary Niger Delta. American Association of Petroleum Geologist, Tulsa.

[20] Ekweozor, C.M. and Okoye, N.V. (1980) Petroleum Source-Bed Evaluation of Tertiary Niger Delta. American Association of Petroleum Geologists Bulletin, 64, 1251-1259. https://doi.org/10.1306/2F919472-16CE-11D7-8645000102C1865D

[21] North, F.I. (1985) Petroleum Geology. Springer, Berlin.

[22] Reijers, T., Petters, S. and Nwajide, C. (1997) The Niger Delta Basin. Sedimentary Basins of the World, 3, 151-172. https://doi.org/10.1016/S1874-5997(97)80010-X

[23] Lehner, P. and De Ruiter, P.A.C. (1977) Structural History of Atlantic Margin of Africa. American Association of Petroleum Geologists Bulletin, 61, 961-981. 
https://doi.org/10.1306/C1EA43B0-16C9-11D7-8645000102C1865D

[24] Dim, C. and Onuoha, K. (2017) Insight into Sequence Stratigraphic and Structural Framework of the Onshore Niger Delta Basin: Integrating Well Logs, Biostratigraphy, and 3D Seismic Data. Arabian Journal of Geosciences, 10, Article No. 300. https://doi.org/10.1007/s12517-017-3070-5

[25] Jev, B.I., Kaars-Sijpesteijn, C.H., Peters, M.P., Watts, N.L. and Wilkie, J.T. (1993) Akaso Field, Nigeria: Use of Integrated 3-D Seismic, Fault Slicing, Clay Smearing, and RFT Pressure Data on Fault Trapping and Dynamic Leakage. AAPG Bulletin, 77, 1389-1404. https://doi.org/10.1306/BDFF8EA2-1718-11D7-8645000102C1865D

[26] Benkhelil, J. (1986) Structure and Geodynamic Evolution of the Intracratonic Benue Trough (Nigeria). Elf Nig. Ltd., Nigeria, Bull Centres Rech. Explor. Prod. Elf-Aquitaine (BCREDP) 12, 29-128.

[27] Garcia, R. (1981) Depositional Systems and Their Relation to Gas Accumulation in Sacramento Valley, California. AAPG Bulletin, 65, 653-673. https://doi.org/10.1306/2F9199A4-16CE-11D7-8645000102C1865D

[28] Rider, M.H. (1986) The Geological Interpretation of Well Logs.

[29] Etu-Efeotor, J. (1997) Fundamentals of Petroleum Geology. Africana-FEP Publishers, Onitsha, 111-123.

[30] Edwards, J.D. and Santogrossi, P.A. (1990) Summary and Conclusions. In: Edwards, J.D. and Santogrossi, P.A., Eds., Divergent/ Passive Margin Basins, AAPG Memoir 48, Tulsa, 239-248.

[31] Adeoti, L., Onyekachi, N., Olatinsu, O., Fatoba, J. and Bello, M. (2014) Static Reservoir Modeling Using Well Log and 3D Seismic Data in a KN Field, Offshore Niger Delta, Nigeria. International Journal of Geosciences, 5, 93-106. https://doi.org/10.4236/ijg.2014.51011 